\title{
タスクオプションを考慮したリスク評価モデルによる 設計開発プロジェクトの最適計画法
}

\author{
野間口 大 $^{* 1}$, 董 春祉 $^{* 2}$, 堀之内 貴大 ${ }^{* 2}$, 藤田 喜久雄*3
}

\section{Optimal planning method of design project based on risk assessment model with task option}

\author{
Yutaka NOMAGUCHI ${ }^{* 1}$, Chunzhi DONG ${ }^{* 2}$, Takahiro HORINOUCHI ${ }^{* 2}$ and Kikuo FUJITA*3

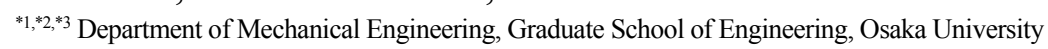 \\ 2-1 Yamadaoka, Suita-shi, Osaka 565-0871, Japan
}

Received: 12 April 2017; Revised: 28 July 2017; Accepted: 3 September 2017

\begin{abstract}
The product design project includes many uncertainties. It causes risk that a project target cannot be accompolished within lead time. In order to flexibly handle the uncertainty and avoid the risk, adaptive planning that can switch easily to another plan by preparing options for a task is needed. When a challenging design alternative is difficult to be accompolished, a project manager should decide either to continue the design taking a risk or to switch to a conservative alternative disliking a risk. This paper proposes a new optimization-based project planning method that aims at a Pareto-optimal of the potential technical performane of designed product and a project failure risk. A task option model is employed for risk assesment of option-based project management. As its planning includes a number of various design variables and various evaluation indices, in order to solve such a complicated problem with a reasonable computation cost, this research separates the optimization problem into two phases, i.e., (i) defining of process architecture and organization structure and (ii) scheduling of resource allocation into activities. This paper demonstrates its application to a student formula design project. A proposed optimization method facilitates a project manager to explore various process plans with assessing their risks.
\end{abstract}

Keywords : Risk management, Project management, Design engineering, Engineering optimization, Design process planning, Option

\section{1. 序論}

設計開発プロジェクトは何らかの新規な製品やサービスを生み出す活動である．設計開発の目標が高く，新規的 であるほど，知識や経験の不足によるプロジェクト失敗のリスクも必然的に高まる. 失敗のリスクに対応するため には, 代替の計画案, すなわちオプションを用意しておき, プロジェクトの進渉を見ながら, 当初の計画を柔軟 に切り替えることも求められる。一方で, プロジェクトに利用できる人的, 物的リソースや時間の制約を考慮す ると, オプションを考慮しながらも, 目標に応じて従来の作業内容を見直したり, リソースの配分を調整したり, 作業の効率化のために新たに組織を編成するといったことも含めて，プロジェクト計画をより合理的に行うこと が重要である.しかしながら, 設計開発プロジェクトの進渉には不確実性を伴う多くの要因が複雑に関連してい るため, 最適化の前提となる評価指標の数理モデルの構築が難しく，その最適解を得るための効果的な手法の確

No.17-00167 [DOI:10.1299/transjsme.17-00167], J-STAGE Advance Publication date : 13 September, 2017

*1 正員, 大阪大学工学研究科機械工学専攻（干565-0871 大阪府吹田市山田丘 2-1)

*2 大阪大学工学研究科機械工学専攻

*3 正員, フェロー, 大阪大学大学院工学研究科機械工学専攻

E-mail of corresponding author: noma@mech.eng.osaka-u.ac.jp 
立は重要な研究課題となっている.

本研究では, 設計開発プロジェクトにおけるタスクオプションの概念を導入し, タスクオプションを考慮したリ スク評価手法とそれに基づくプロジェクト計画手法の確立を目的とする. プロジェクト計画案の評価指標として, プロジェクト目標が達成された場合に期待できる製品性能の高さと，知識・経験不足による目標達成失敗のリス クの 2 つの視点に着目し, その下で最適な解を得ることを目指す．この計画問題は多くの設計変数を含んだ非常 に複雑な多目的最適化問題となる. その解法を, 著者らのグループが提案している二段階多目的最適化法 (野間口 他, 2012)に基づいて構築する. 提案した計画法を学生フォーミュラプロジェクトの計画問題に適用し検証を行う.

\section{2. オプションについての関連研究}

オプションは不確実性を报うための有効な概念であり，主に経済学の分野で研究，開発されてきた．もともと は金融界で，何らかの資産を特定の条件下で特定の期間に売り買いする権利を保障する証券を意味する用語であ る (Black and Scholes, 1973) . 当初は株式を対象とするものであったが, その後, リアルオプションと呼ばれる, 様々な資産を対象するオプションも考案されている (Myers, 1984) 。 リスク中立の考え方と確率計算の下で, オプ ションの価值を求めるオプション理論が盛んに研究されており (日本リアルオプション学会, 2006), 製品設計開 発プロジェクトに関する経営判断の支援に応用する研究も行われている (江口他, 2015).

設計工学分野においては，製品のモジュール設計に利用することを目的とするアーキテクチャオプション理論 が提案されている (Baldwin and Clark, 2000)。これは, 製品システムに対する要求が将来に変化するリスクを軽減 するような, モジュール構造の価值を算出するものである. アーキテクチャーオプションとは, モジュール化さ れたサブシステムの設計代替案を意味する. オプションが豊富であれば, 要求の変化に柔軟に対応して, より多 くの価值を生むことができる，一方で, 多くのオプションを用意するためには, 多額の設計, 開発のコストが必 要となる. アーキテクチャーオプション理論は, このようなコストを考慮して, オプションの価值を定量的に与 える.リアルオプション理論の考え方を導入して, アーキテクチャーオプションの価值を評価する研究も行われ ている (Sullivan et al., 2001, Sharman and Yassine, 2007, Engel and Browning, 2008) 。これらの研究では, 製品を構 成するサブシステムについての複数の設計代替案を想定し, 要求の変化などの各種リスクの大きさを見積もる確 率モデルを導入している.

一方で, 設計開発プロジェクトマネジメントの観点からも, 様々な不確実要因に基づくリスクの分析法の開発 が行われている．例えば，状態遷移ネットワークを用いて設計プロジェクトのある部分の内容の変更が他の部分 に与える影響を分析する手法 (Shapiro et al., 2016), リスク要因間の因果関係をネットワーク理論に基づく方法で 明示化し，リスクの伝播の影響を分析する手法 (Fang et al., 2012) などが開発されている.オプションの設計開発 プロジェクトマネジメントへの応用を試みる研究も見られる。例えば, Koh ら (Koh et al., 2012) は QFD (Quality Function Deployment) と DSM (Design Structure Matrix) を用いて, 要求とアーキテクチャオプションを関連付け, 設計変更の伝播を考慮することによってオプションを切り替えるにあたって発生する潜在的なコストを予測する 手法を提案している.

リアルオプションやアーキテクチャーオプションについての上記の既存研究では, 市場における要求の変化をリ スク要因と捉え, その下でのオプション価值に着目している. 一方で, 設計開発プロジェクト計画に関わる要因 を直接扱ってはいないため，そのままでは，具体的に設計開発を進めるプロジェクトマネージャーを支援する手 法としては利用できない. また, 上述した従来の設計開発プロジェクトマネジメントの支援手法は, どちらかと 言えばプロジェクトの静的な性質に着目したリスク分析に留まっており, チーム編成やリソース配分, スケジュー リングなどの設計開発プロジェクトの進渉に関連する要因を直接扱ってはいない. 本研究の新規性は, 設計開発 プロジェクトの進渉に関連するオプションとしてタスクオプションの概念を導入することにより，その下でのリス ク評価を合理的に行うことを試みる点にある.

\section{3. 設計開発プロジェクト計画の課題とオプションによるアプローチ}

本章では, 設計開発プロジェクト計画の課題を整理し, オプションの適用に向けた本研究のアプローチを述べる. 


\section{$3 \cdot 1$ 設計開発プロジェクトにおけるリスクの対応}

設計開発プロジェクトにおいては不確実性に対応するために，ある種のマイルストーン管理，すなわち，定期 的に行われるデザインレビューにおいて実際の進渉と当初の計画を比較して, 遅れがないかどうかを確認しなが ら進められることが一般的である，もし，設計が計画通り進まず，そのままでは期限までに目標が達成できない と判断されれば，設計時間や人員を増やすなどのてこ入れを行う。それでも間に合わないと判断されれば，当初 の目標を下げてでも, より確実な設計案へ変更し, 期限に間に合わせることを試みる. その場合, 途中で計画を 切り替えることによって, プロジェクトの他の部分への影響が波及することも考える必要がある.

\section{$3 \cdot 2$ 知識獲得プロセスの視点の下での各種要因}

作業の内容が明確である生産プロセスなどとは異なり, 設計開発プロセスは進行と同時に作業の内容を決めて いく知識獲得のプロセスである (Nonaka and Krogh, 2009). 時間をかけることにより獲得される知識量が増え, そ れに対応して設計の内容が洗練される．そのような作業の進渉は，費やす設計時間のほか，製品が一般に複数の サブシステムから構成されることに着目すると，サブシステム間の依存関係や，サブシステムの設計を専門に行 うグループの編成，グループ内およびグループ間の協調作業の効率，担当する設計者の能力，作業難度など，様々 な要因の複雑な相互作用に依存する.

例えば, サブシステムの設計の到達度を向上させるには，そのサブシステムについての知識が豊富で優秀な設 計者を担当させ, 十分な設計時間を確保することが重要となる，一方で, サブシステム間の依存関係に起因して, あるサブシステムの設計が別のサブシステムの設計に悪影響を及ぼし, 設計のやり直し (リワーク) が発生する可 能性がある. そのためサブシステム間で整合を取って無用のリワークの発生を防ぐ「すり合わせ」の作業も必要 である (Clark and Fujimoto, 1990). サブシステム間のすり合わせの作業の効率に関しては一般に，依存関係の強い サブシステムの設計タスクを同じタスクグループで担当する方が高く，また，そのタスクグループの参加者数が 少ない方が高いことが指摘されている (Eppinger et al., 1994) .

このように設計開発プロジェクト計画問題には，知識獲得に関わる様々な要因が関係しており，計画の全体最適 解を得るにはそれらを考慮してリスク評価を行うための数理モデルが要求される.

\section{$3 \cdot 3$ 設計開発プロジェクト計画の多目的性}

設計開発プロジェクト計画の評価の視点として, プロジェクト目標が達成された場合に期待できる製品性能の高 さと, 知識・経験不足による目標達成失敗のリスクの 2 つ視点を考えた場合, 両者は一般にトレードオフの関係 にある. 後者については, 設計対象がシステムであることを考えると, 個別のサブシステムの設計の到達度に起 因するリスクと，サブシステム間の設計の整合度に起因するリスクの 2 つ視点に分類することができる．到達 度の向上に多くの時間を費やすと，個々の技術要素の性能は高いが全体のすり合わせが不十分な製品になる．逆 に, 整合度の向上に多くの時間を費やすと, 全体としてのまとまりはあるが個々の技術的な到達度は低いものに なる. すなわち，プロジェクト目標の達成可能性の評価の際には，個々のサブシステムの到達度と全体としての 整合度の 2 つの視点が必要である. 限られたリソースのもとでは, この2つもトレードオフの関係にある.

このような多目的性のもとでの評価は 3.1 節で述べたマイルストーン管理を考慮するとさらに複雑なものとな る. なぜなら, ある計画案の評価を行う際に, それを途中で切り替えた場合の様々な影響を考慮する必要がある からである.

\section{$3 \cdot 4$ 最適計画手法構築に向けたアプローチ}

以上の議論をまとめると, 設計開発プロジェクトの最適計画を実現する上では以下の 3 つの課題に取り組む必 要がある.

1. 3.1 節で述べたように, マイルストーン管理と計画案の切り替えのもとでのリスク評価を考慮すること.

2. 3.2 節で述べたように, 設計者の能力や作業の難度, コミュニケーション効率, 設計プロセス構造, 組織構造, 時間配分といった, 知識獲得プロセスに関連する様々な要因を考慮すること.

3. 3.3 節で述べたように，プロジェクト計画の多目的性を考慮すること.

これらの課題に対し, 本研究では次のようなアプローチを取る. まず, 課題 1 に対しては, 設計開発プロジェク 
トにおけるタスクオプションの概念を確立する. 課題 2 に対しては, 設計が知識獲得のプロセスである点を考慮 し, 著者らの先行研究で提案している成長曲線によるプロジェクト進渉予測モデル (野間口他, 2009)に基づいて, それぞれの評価指標の数理モデルを構築する. 最後に, 課題 3 に対しては, 最適化に向けた評価指標として性能ポ テンシャルと目標達成失敗リスクの 2 つ視点を導入し, 後者についてはさらにサブシステムの設計の到達度の 目標とサブシステム間の設計の整合度の目標の 2 つを考慮して, それらのもとでのパレート最適解を求める. そ の際に, 全体の計画問題を, 設計プロセス構造や組織構造などの決定問題と, リソースのスケジューリング問題 の 2 つつェーズに分けて定式化し, 両者の連携により全体の計画問題の解を求める.

\section{4. 設計開発プロジェクトにおけるタスクオプションの基本概念}

\section{$4 \cdot 1$ 設計開発プロジェクトの構造}

本研究ではタスクオプションの概念を導入するにあたり, 設計開発プロジェクトの内容を, 図 1 に示すように タスク, タスクグループ, 設計者, タスク代替案の 4 つの基本要素で考える.

タスクグループは, プロジェクトの組織構造の一部であり, 複数のタスクによって構成される. タスクは, 設 計プロセスの基本構成要素であり，個々のサブシステムに関連する設計の到達度を向上させる活動である．それ ぞれのタスクに対して，設計の方針の代替案が存在し，これをタスク代替案と呼ぶ．タスク代替案の特徵を表現 するため, 本研究では, 性能ポテンシャル $v$ とタスク難度 $m$ の 2 つのパラメータを導入する. 前者は, 設計の目 標 $f_{T}$ が達成されたときに期待できる性能の高さを表す． なお， ここでの性能とは設計対象の性質や能力である. コスト低減や設計開発期間短縮といった効果は別途評価すべきものと考え，性能には含めないこととする．後者 は目標達成が失敗する可能性の高さを表す.一般に, 性能ポテンシャルの高いタスクは難度も高い. また, サブシ ステムは互いに依存関係があるため，それに対応してタスクにも依存関係が存在する． 本研究では，異なるタス クの代替案の間に，依存度 $r$ のパラメータを導入する. 依存度が高いほど, タスク間のすり合わせにより多くの 時間が必要となる. また, 必要タスクの代替案を変更したときに, 他のタスクへの影響が大きくなる.

設計者は，プロジェクトの人的リソースである. 設計者はそれぞれに専門的知識や経験を持ち，その能力に応 じて 1 つ以上のタスクを担当する. 本研究では, 各タスク代替案について各設計者が持っている知識・経験の高 さを表すために, 初期到達度のパラメータ $f_{0}$ を導入する. 設計者は担当タスクに応じてタスクグループに所属す ることになる。

\section{$4 \cdot 2$ デザインレビューミーティングとマイルストーン管理}

ミーティングは, タスク間の整合度を向上させる活動である. ミーティング時に設計者は依存関係のあるタスク に対して整合がとれているかどうか確認を行う. デザインレビューミーティング (DR) は，プロジェクトメンバー 全員が参加するミーティングである. DR 時点での各タスクの到達度がマイルストーンとなる. プロジェクトマ ネージャーは，DRに执いて各タスクが計画通りに進渉しているかどうかを確認する．計画通りに進渉していない 場合, 必要に応じて計画を修正して対応する.

\section{$4 \cdot 3$ タスクオプション}

タスク代替案の選択打よび切り替えの判断は, プロジェクト計画における重要な要素である. 本研究では, 各 タスクについて, 計画立案時点より後の DR でのタスク代替案の切り替えを計画したものをタスクオプションと 呼ぶ. 図 2 は, $A_{i, 1}$ と $A_{i, 2}$ の 2 つタスク代替案があるタスク $i$ にいて, $A_{i, 1}$ を実施しているところに, $\mathrm{DR}_{z} に$ おいて計画の修正を考える状況で，プロジェクト期間終了まで 2 回の $\mathrm{DR}\left(\right.$ すなわち $\mathrm{DR}_{z+1}, \mathrm{DR}_{z+2}$ )を実施する場 合に想定できるオプションを列挙したものである. なお, $A_{i, 1}$ の方が, $A_{i, 2}$ よりも性能ポテンシャル, タスク難度 のどちらも高いものとする.

計画時点からプロジェクト終了まで，同一のタスク代替案を実施し続ける計画を優先オプション (priority option) と呼ぶ. 図 2 の例の場合, $O_{i, 0}^{1}$ は $A_{i, 1}$ についての, $O_{i, 0}^{2}$ は $A_{i, 2}$ についての優先オプションである. 計画時点では挑 戦的なタスク代替案を実施するものの, プロジェクトの途中でよりリスクの少ないタスク代替案に切り替える計 画を, バックアップオプションと呼ぶ. 図 2 の例の場合, $O_{i, z+1}^{1}, O_{i, z+2}^{1}$ はそれぞれ $\mathrm{DR}_{z+1}, \mathrm{DR}_{z+2}$ で $A_{i, 1}$ から $A_{i, 2}$ 


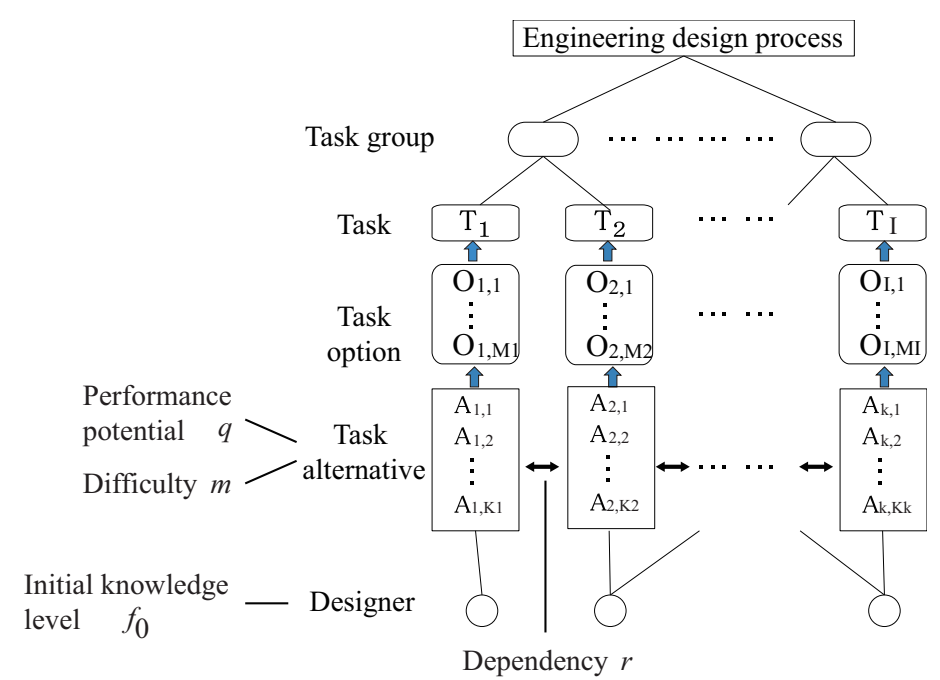

Fig. 1 Structure of design project consists of four basic elements i.e., task group, task, task alternative and designer.

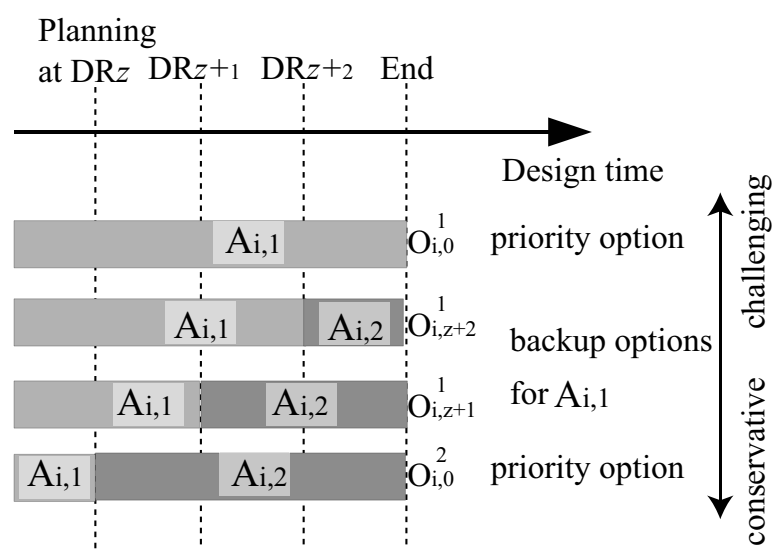

Fig. 2 Task option is defined as a plan of switching or continuing task alternatives as for all DRs.

に切り替えるオプションであり, いずれも $A_{i, 1}$ のバックアップオプションである. $O_{i, 0}^{2}$ もタスク代替案を切り替え てはいるが, 計画時点での変更であるため, バックアップオプションには該当しない.

なお, 本研究では, 計画時点で考慮するバックアップオプションは, タスク代替案の切り替えがプロジェクト終 了まで 1 回のものとする.

\section{5. タスクオプションを考慮したリスク評価モデル}

前章で述べたタスクオプションのもとでのプロジェクト計画のリスク評価を行うための, 目標達成確率扰よび 性能ポテンシャルの評価モデルを説明する.

\section{$5 \cdot 1$ 目標達成確率によるリスクの表現}

本節では, まず, オプションの切り替えを考慮に入れない場合, すなわち, すべてのタスクで優先オプションを 採用した場合のリスクの評価を, 著者らが提案しているプロジェクト進渉予測モデルによって行う. なお, 本報で は概略を述べるに留め, 詳細は文献 (野間口他, 2009)に譲る.

\subsection{1 成長曲線によるプロジェクト進渉予測}

このモデルでは, 各タスクの到達度およびタスク間の整合度を，0から 1 までの数で表現し, プロジェクトの進 渉に応じてそれぞれ上昇していくとする. 著者らの先行研究 (野間口他, 2009) において, 設計者が設計対象に対 して何も知識を有していない状態を 0 , あらゆる知識を有し完璧な最適設計が可能な状態を 1 とし, その間を解析 モデルや製品の使用条件に対する理解の程度に応じて定義している. 本研究でもこの方法を利用する. それぞれ の目標も 0 から 1 の間で設定し, プロジェクトの進渉と目標との比較を行えるようにする.

具体的にはまず，タスクの到達度を以下の式の成長曲線を用いてモデル化する.

$$
f_{i}(t)=1-\left(1-f_{0 i}\right) \exp \left(-m_{i} \tau_{i}(t)\right)
$$

ここで $f_{i}(t)$ はタスク $i$ の到達度, $m_{i}$ は難易度に相当するパラメータである. $m_{i}$ は值が小さいほど難度が高いこと を示す. 不確実性を表すため, いずれも三角ファジィ数で与える. $f_{0 i}$ は担当設計者のタスク $i$ の初期到達度で, 設 計者の能力を表すパラメータである. $\tau_{i}(t)$ は時刻 $t$ までにタスク $i$ に費やした時間である. なお, $m_{i}$ の值につい ては, 著者らの先行研究 (野間口他, 2009) において, プロジェクト期間内の 2 つの時点における到達度から計算 する方法を提案している. 本研究でもこの方法を利用する.

タスク $i$ とタスク $j$ の整合度 $g_{i j}(t)$ は, 両タスクについてのミーティングを行うことにより上昇する. 整合度の 上昇量はタスクの依存度とミーティング効率によって変化する. またミーティング時の設計者が有するそれぞれ 
のタスクに対する知識量が整合度の上限となる．このような特徵を反映させ，整合度を以下の式で表現する.

$$
g_{i j}(t)=\left(\sqrt{f_{i}(t) f_{j}(t)}-g_{i j 0}\right)\left(1-\exp \left(-\alpha \frac{e}{\frac{r_{i j}+r_{j i}}{18}} \tau_{i j}(t)\right)\right)+g_{i j 0}
$$

ここで, $\tau_{i j}(t)$ は時刻 $t$ までにタスク $i$ とタスク $j$ のミーティングを行った時間, $g_{i j 0}$ は前回のミーティング終了 時での整合度 $($ 初期值は 0 ) である. e はタスク間の関係に応じて変化するミーティング効率であり, 三角ファジィ 数で与えられる. また, $r_{i j}$ はタスク $i$ に対するタスク $j$ の依存度であり, $0,1,3,9$ で表される. 数值が大きいほど タスク間の依存度が高いことを示し，その整合度の向上にはより多くのミーティング時間が必要となる． $\alpha$ は整 合度の上がりやすさを調整するパラメータである.

\subsection{2 リワークによる到達度の減少}

ミーティングにおける検討の結果, 設計を修正すると, 修正箇所に依存している他の部分を修正するためにリ ワークが生じ，到達度が減少する，すなわち，ミーティングにより当該タスク間の整合度は向上するが，タスク の到達度は減少することになる，ただし整合度が高いほど，到達度の減少量は少なくなると考えられる．

以上の事象を表すために，本研究では，まず，ミーティング終了時の到達度を以下の式で与える.

$$
f_{i}\left(t_{e}\right)=f_{i}\left(t_{b}\right)-\sum_{j=1, j \neq i}^{N} \Delta f_{i j}
$$

ここで, $f_{i}\left(t_{b}\right)$ と $f_{i}\left(t_{e}\right)$ はミーティング開始時と終了時のタスク $i$ の到達度を表している. また, $\Delta f_{i j}$ はミーティン グ終了時のタスク $j$ の影響によるタスク $i$ の到達度の減少量であり以下の式で表される.

$$
\Delta f_{i j}=\beta r_{i j}\left(1-g_{i j}(t)\right) \Delta f_{i}
$$

ここで, $\Delta f_{i}(t)$ は前回のミーティングからのタスク $i$ の到達度の増加量, $\beta$ は到達度の減少に対する影響の度合い を表すパラメータである.

\section{$5 \cdot 1 \cdot 3$ 達成確率}

タスク $i$ の到達度の目標達成確率 $p_{i}$ は到達度の三角分布の中で, 目標到達度 $f_{T i}$ を上回る面積の割合によって 算出される. 三角分布が関数 $\mu_{i}$ で表される時, タスク $i$ の到達度の目標達成確率 $p_{i}$ は以下の式で与えられる. な お， $f_{L i}, f_{U i}$ はそれぞれ三角分布の最小值と最大值である.

$$
p_{i}=\frac{\int_{f_{T i}}^{f_{U i}} \mu_{i}(f) d f}{\int_{f_{L i}}^{f_{U i}} \mu_{i}(f) d f}
$$

同様の計算方法で, 整合度の目標達成確率 $q_{i j}$ が与えられる.

\section{2 タスクオプションの下での評価}

前節で導入したプロジェクト目標達成確率は, タスクオプションを考慮することによって向上させることがで きる. 本節ではその計算方法を述べる.

\subsection{1 リスク選好のモデル}

バックアップオプションを選択するかどうかは, 設計開発プロジェクトにおけるリスク選好の度合いに依存し て決まると考えられる. 例えば, プロジェクトのリスク選好が強ければ, 優先オプションでは目標を達成するこ とが困難な場合でも, ポテンシャルの高い優先オプションをそのまま続けることも考えられる.

以上のことを踏まえ, プロジェクトマネージャーの判断をモデル化する. 具体的には, 計画時点より後に実施 予定のある $\mathrm{DR}_{z}$ において, タスク $i$ にいてより低リスクかつ低ポテンシャルの代替案への切り替えを行う確率 $c_{i, z}^{\prime}$ を数值化する. 図 3 はその概略を示したものである. ここで, リスク選好の度合いを示すパラメータとして, 


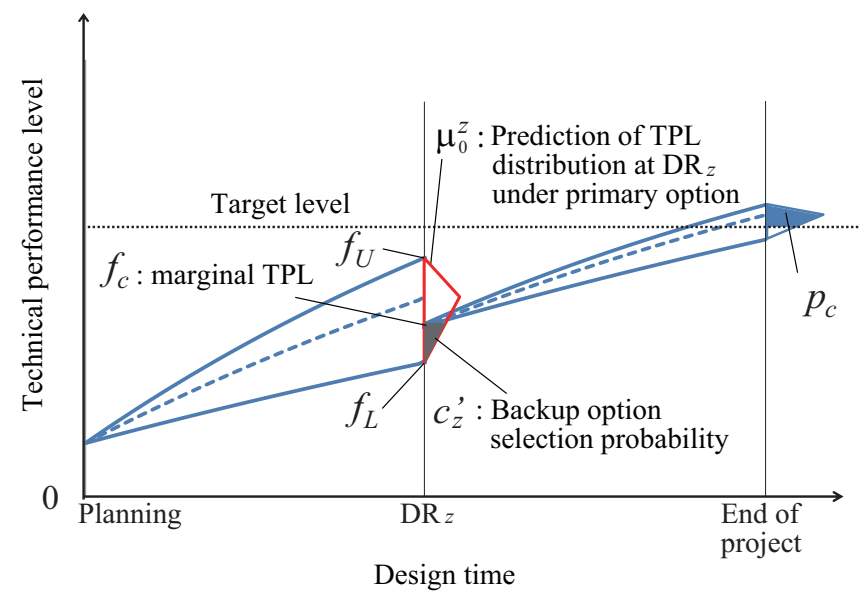

Fig. 3 Backup option selection probability $c_{z}^{\prime}$ is equaled with the area under the marginal TPL $f_{c}$ of $\mu_{0}^{z}$.

許容達成確率 $p_{c}$ を導入する. なお, タスク $i$ について, 計画時点からみて $z$ 回目 $(\mathrm{z} \geq 1)$ の $\mathrm{DR}\left(\right.$ すなわち, $\left.\mathrm{DR}_{z}\right)$ で切り替えるバックアップオプションを $O_{i, z}$ と表す. $O_{i, 0}$ は優先オプションを表すとする. また, $\mathrm{DR}_{z}$ 時点で選 択できるタスク代替案が複数存在する場合, 最も性能ポテンシャルの高いタスク代替案によるバックアップオプ ションを想定する.

まず, 式(1)〜(4)により, 現状の $O_{i, 0}$ のもとでの $\mathrm{DR}_{z}$ の時点での到達度の三角分布 $\mu_{i, 0}^{z}(f)$ を求める. 次に, 式 (5) により， $O_{i, 0}$ のもとでプロジェクト終了まで実施した時の目標達成確率 $p_{i, 0}$ を以下の式で求める.

$$
p_{i, 0}=\int_{f_{L i}}^{f_{U i}} \mu_{i, 0}^{z}(f) p_{i, 0}^{z \rightarrow f i n}(f) d f
$$

なお, $p_{i, 0}^{z \rightarrow f i n}(f)$ は, $\mathrm{DR}_{z}$ での到達度が $f\left(\right.$ ただし, $\left.f_{L} \leq f \leq f_{U}\right)$ のときに $O_{i, 0}$ のもとで $\mathrm{DR}_{z}$ からプロジェクト終了 までタスクを実行したときの到達目標達成確率である.

同様に, バックアップオプション $O_{i, z}$ を選択した場合のプロジェクト終了時点での目標達成確率 $p_{i, z}$ を以下の式 で求める.

$$
p_{i, z}=\int_{f_{L i}}^{f_{U i}} \mu_{i, 0}^{z}(f) p_{i, z}^{z \rightarrow f i n}(f) d f
$$

なお, $p_{i, z}^{z \rightarrow f i n}(f)$ は, $\mathrm{DR}_{z}$ での到達度を $f$ としてバックアップオプション $O_{i, z}$ のもとでプロジェクト終了までタス クを実行したときの到達目標達成確率である.

上記で定義した $p_{i, 0}, p_{c}, p_{i, z}$ の関係に基づいて,$c_{i, z}^{\prime}$ の数理モデルを構築する. まず，以下の不等式を満足すると きには $O_{i, 0}$ を断念して $O_{i, z}$ を選択する余地があり (すなわち, $c_{i, z}^{\prime} \neq 0$ ), それ以外の場合はバックアップオプショ ンのメリットがないまたは少ないとみて $O_{i, 0}$ を継続して実施 (すなわち,$c_{i, z}^{\prime}=0$ ) とする.

$$
p_{i, 0} \leq p_{c} \leq p_{i, z}
$$

式 (8) が成り立つとき，もし， $p_{i, 0}^{z \rightarrow f i n}\left(f_{L i}\right) \leq p_{c} \leq p_{i, 0}^{z \rightarrow f i n}\left(f_{U i}\right)$ となるならば，ちょうど $p_{i, 0}^{z \rightarrow f i n}\left(f_{c i}\right)=p_{c}$ となる到達 度 $f_{c i}$ が $\left[f_{L i}, f_{U i}\right]$ の区間に存在する． $f_{c i}$ は， $\mathrm{DR}_{z}$ での到達度がそれを下回っていれば， $O_{i, 0}$ のもとでの目標達成確 率が $p_{c}$ を下回る限界の到達度である. 本研究では, この $f_{c i}$ を用いて, $c_{i, z}^{\prime}$ を, 図 3 のように $\mu_{i, 0}^{z}(f)$ の三角分布 のうち $f_{c i}$ を下回る部分の面積の割合として表す．なお， $p_{c}<p_{i, 0}^{z \rightarrow f i n}\left(f_{L i}\right)$ の場合は $f_{c i}=f_{L i}, \quad p_{i, 0}^{z \rightarrow f i n}\left(f_{U i}\right)<p_{c}$ の 場合は $f_{c i}=f_{U i}$ とする.

以上をまとめると， $c_{i, z}^{\prime}$ は以下の式で与えられる.

$$
c_{i, z}^{\prime}= \begin{cases}0 & (\text { 式 (8) が成立しないとき) } \\ \frac{\int_{f_{L i}}^{f_{c i}} \mu_{i, 0}^{z}(f) d f}{\int_{f_{L i}}^{f_{U i}} \mu_{i, 0}^{z}(f) d f} & (\text { 式 (8) が成立するとき) }\end{cases}
$$




\section{$5.2 \cdot 2$ オプション選択確率}

式(9)の $c_{i, z}^{\prime}$ は, $\mathrm{DR}_{z}$ の時点でみた $O_{i, z}$ の選択確率である. 一方で, 計画時点でみた $O_{i, z}$ の選択確率 $c_{i, z}$ は, $\mathrm{DR}_{z-1}$ までに バックアップオプションが選択されていない条件の下での確率となる. また， $O_{i, 0}$ が採用される確率 $c_{i, 0}$ は，どのバックアップオプションも選択されない確率として与えることができる. 以上を踏まえ， $c_{i, z}$ を以下の式 で与える.

$$
c_{i, z}= \begin{cases}c_{i, z}^{\prime} \prod_{z^{\prime}=1}^{z-1}\left(1-c_{i, z^{\prime}}\right) & (1<z \leq R) \\ c_{i, 1}^{\prime} & (z=1) \\ 1-\sum_{z^{\prime}=1}^{R} c_{i, z^{\prime}} & (z=0)\end{cases}
$$

なお, $R$ は計画時点からプロジェクト終了までの DR の総数である.

\section{$\mathbf{5 \cdot 2 \cdot 3}$ 期待値による計算}

式 (6) または式 (7) を用いて, タスク $i$ につてあるオプションを採用した場合の到達度目標達成確率を計算す ることができる．また，式(10)を用いて，各タスクオプションの選択確率を計算することができる．これらを用 いて, タスク $i$ の到達度目標達成確率 $\tilde{p}_{i}$ を, タスク $i$ のすべてのオプションのもとでの目標達成確率の期待值の 和で与える. 具体的には以下の式で与える.

$$
\tilde{p}_{i}=\sum_{z=0}^{R} c_{i, z} p_{i, z}
$$

同様に，整合度に関してもそれぞれのタスク間において，すべてのオプションを考慮した整合度目標達成確率 の期待值を求め, それぞれのタスク間の整合度目標達成確率とする. 具体的には, タスク $i$ とタスク $j$ の整合度目 標達成確率を以下の式で与える.

$$
\tilde{q_{i j}}=\sum_{y=0}^{R} \sum_{z=0}^{R} c_{i, y} c_{j, z} q_{i j, y z}
$$

ここで, $q_{i j, y z}$ は, タスク $i$ のオプション $O_{i, y}$ とタスク $j$ のオプション $O_{j, z}$ 間の整合度である.

性能ポテンシャルについても同様にすべてのオプションを考慮した期待值を計算したものをタスク $i$ の性能ポテ ンシャル $\tilde{v}_{i}$ とする.

$$
\tilde{v_{i}}=\sum_{z=0}^{R} c_{i, z} v_{i}
$$

ここで, $v_{i}$ は $O_{i, z}$ においてプロジェクト終了時点で実施されているタスク代替案の性能ポテンシャルである.

\subsection{4 代替案切替による他のタスクへの影響の評価}

バックアップオプションの選択により, プロジェクト途中であるタスク $i$ の代替案 $A_{i, j}$ の実施を打ち切り, 他の 代替案 $A_{i, k}$ に切り替えたときに，それまで実施していた $A_{i, j}$ の設計の内容の一部は， $A_{i, k}$ の設計にも流用できると 考えられる. また，その時に流用できる作業量はタスク代替案間の類似度に依存して決まると考えられる. 本研 究ではこの事象をモデル化するために, 2 つのタスク代替案 $A_{i, j}$ と $A_{i, k}$ の間の類似度 $S_{i, j k} \quad\left(0 \leq S_{i, j k} \leq 1\right)$ のパラ メータを導入し, 式 (1) および式 (2)において, 時間 $\tau$ に乗じて, タスク代替案を切り替えた時点での到達度およ び整合度を計算することとする。

本研究では, 類似度 $S_{i, j k}$ を以下のように定義する. タスク代替案 $A_{i, k}$ の優先オプションのもとでの開始から完 了までの時間が $\tau_{i, k}$ であるとする. 一方で, タスク代替案 $A_{i, j}$ を $\tau_{i, j}\left(0<\tau_{i, j}\right)$ だけ実施した後に $A_{i, k}$ に切り替える と, 切り替え時点から $A_{i, k}$ の完了までの時間が $\tau_{i, k}^{\prime}\left(\tau_{i, k}^{\prime} \leq \tau_{i, k}\right)$ であるとする. このとき, $S_{i, j k}=\frac{\tau_{i, k}-\tau_{i, k}^{\prime}}{\tau_{i, j}}$ である. 実 際の計算においては, $A_{i, j}$ と $A_{i, k}$ の作業内容を調べて流用できる作業項目の数から $S_{i, j k}$ を数值化することが考えら れる. 本研究の計算例においてもそのような運用を行っている. 


\section{$5 \cdot 3$ 目的関数の構成}

個別のタスクについての評価指標である式 (11)〜(13) に基づいて, 下記の要領でプロジェクト全体の評価指標 を構成する.

設計プロセスを構成する各タスクは同時並列的に行われる一方で, 設計プロセス全体からみると，どのタスク も必要不可欠という意味では設計プロセスは一つの直列システムであるとみなすことができる. そこで, 各タス クの評価指標を相乗平均をとり, プロジェクト全体の評価指標とする. 具体的には, 到達度の目標達成確率 $P$, 整 合度の目標達成確率 $Q$, 性能ポテンシャル $V$ を以下の式で与える.

$$
\begin{aligned}
& P=\left(\prod_{i=1}^{N} \tilde{p}_{i}\right)^{\frac{1}{N}} \\
& Q=\left(\prod_{i=1}^{N} \prod_{j=i+1}^{N} \tilde{q_{i j}}\right)^{\frac{2}{N(N-1)}} \\
& V=\left(\prod_{i=1}^{N} \tilde{v}_{i}\right)^{\frac{1}{N}}
\end{aligned}
$$

ここで, $N$ はタスクの総数である.

\section{6. タスクオプションを考慮した計画問題の構成と解法}

前章の内容に基づき，本研究では下記の計画問題を設定する.

設計変数 各タスクにおけるオプションの考慮の可否, タスクの担当設計者, タスクグループの編成, タスクと ミーティングの実行時間と実行のタイミング

制約条件 タスク，タスク代替案，設計者，各タスクの到達度とタスク間の整合度の目標，設計期間

目的関数 プロジェクト全体の性能ポテンシャル, 到達度の目標達成確率, 整合度の目標達成確率

計画問題の設計変数に着目すると, 各タスクのオプション考慮の可否と担当設計者の配分, タスクグループの 決定は組織構造についての計画問題に関する変数, タスクとミーティングの実行時間と実行のタイミングはスケ ジューリングについての計画問題に関する変数である. そこで, それぞれの計画問題に対応する以下の 2 つのェー ズを設定し，その連携により全体の計画問題を解くことを考える.

フェーズ 1 : プロジェクト組織構造の決定 タスクオプションの採用可否, 設計者の担当タスクとタスクグルー

プを決定する.

フェーズ 2 : 時間配分の決定 タスクとミーティングの実行時間とそのタイミングを決定する.

計画問題の性質上，2つのフェーズには包含関係が存在しており，フェーズ 2 の解はフェーズ 1 の解を与条件と して決定されることになる. 著者らの先行研究 (野間口他, 2012)では，オプションを考慮しない設計開発プロジェ クト計画について, 2つのフェーズを連係して解くためのアルゴリズムを提案しており, 本研究でも利用すること とする. 図4 にその概略を示す. まず, フェーズ 1 で得たパレート解 (図 4 の $\mathrm{PO}_{1}$ ) の中から $n$ 個の解を選択する. その $n$ 個の解のそれぞれを与条件として, フェーズ 2 の最適化計算を行い, それぞれのパレート解 (図 4 の $\mathrm{PO}_{2}$ ) を得る. そこで得た $n$ 個の $\mathrm{PO}_{2}$ を重ね合わせて得られた解集合の中で, パレート解となっているものを選択し, 全体問題の解とする (図 4 の $\mathrm{PO}_{t}$ ).

\section{7. 計 画 例}

\section{$7 \cdot 1$ 学生フォーミュラープロジェクト}

大阪大学学生フォーミュラープロジェクト OFRAC (Osaka university RAcing Club) の計画問題を例として取り上 げ, 提案手法の有効性を検証する. OFRAC は全日本学生フォーミュラ大会に参加するために組織されたクラブで, 2010 年大会では優勝を飾るなど優秀な成績を収めている. 毎年, 約 20 名の大阪大学の学部生, 院生が参加し, 約 3ケ月の期間をかけて大会に参加する車両の設計・開発を行っている. 学生の卒業や入学によりメンバーは毎 


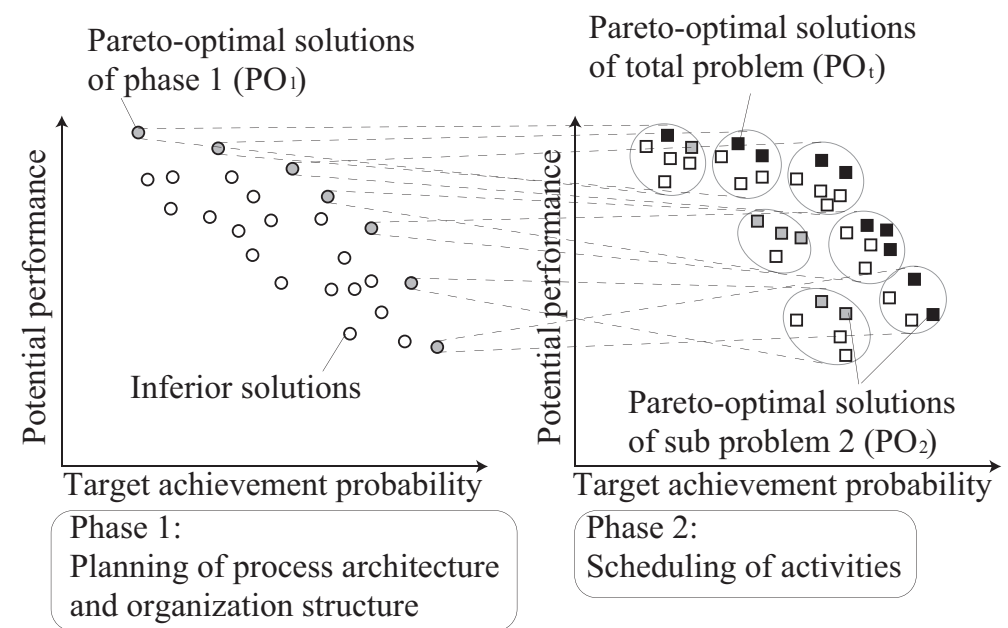

Fig. 4 Due to the characteristics of planning problem, the two phases have a containment relationship. Paretooptimal solution of the phase 1 gives the condition of the phase 2. First of all, the $n$ representative solutions are chosen from $P O_{1}$. They are given to the calculation of the phase 2 as a condition. Optimization calculation of the phase 2 is performed to obtain Pareto-optimal solutions $P O_{2}$ for each of $P O_{1}$. Finally, Pareto-optimal solutions of the whole problem $\mathrm{PO}_{t}$ are obtained by choosing ones from a solution set which is given by superimposing the $n$ solution sets of $\mathrm{PO}_{2}$.

年入れ替わり, 初心者から熟練者まで様々な知識のレベルのメンバーが存在する. また，前年よりも良い車両を製 作するため, 毎年, 新たな技術を取り入れた設計を行っている. 本プロジェクトは規模や内容の点で企業におけ る設計開発プロジェクトには及ばないものの, 以上の内容は一般的な設計開発プロジェクトの性質に対応するも のであり, また, 高い水準の工学知識と新規なアイデアが求められるプロジェクトとなっている. このことから, 本研究の例題として適切と考える.

OFRAC のメンバーにプロジェクトについての聞き取り調査を行い, 本研究で提案する計画手法に必要な各種の 情報, すなわち, タスクやその代替案, タスクの難度, タスク間の依存関係, 設計者の能力などを収集した. 著者 らのグループでは, こうした調査を先行研究 (野間口他, 2009, 野間口他, 2012)でも行っており, その調査方法を 踏襲した. 本プロジェクトは 29 個のタスクで構成され, メンバーは, 大阪大学工学部の学部生, 大学院生 15 名 である. 収集した情報のうち, タスクの代替案, それぞれの難易度 $m$, 性能ポテンシャル $v$, 到達度の目標 $f_{T}$ を 表 1 に示す. タスク代替案は難度の高い順に示している. 図 5 に OFRAC のタスクグループの構造, およびタスク 代替案間の依存度 $r$, 類似度 $S$ をDSM (Design Structure Matrix), DMM (Domain Mapping Matrix) 形式で示す. 各 タスクに対するプロジェクトメンバーの初期到達度を表 2 に示す. 表 3 に各タスクに費やした設計時間とデザイ ンレビュー (DR), 各タスクグループのミーティングに費やした時間, 各タスクを担当した設計者を示す.

また，過去のプロジェクトデータや今回収集したデータを利用して，5 章で述べた評価モデルの調整パラメータ の值を決定する. 具体的には, タスク依存度, タスク難度, 設計者の初期到達度, 到達度の目標, 整合度の目標の 各データと, 実際のプロジェクトにおける設計組織と時間配分の内容を評価モデルに与えて, プロジェクト終了時 点での各タスクの到達度を計算し, それが実際の到達度に合うように, パラメータを調整する. このように調整し たパラメータ值は過去のプロジェクトのデータに基づくものであるが, 同種のプロジェクトであれば值に大きな違 いは出ないと仮定して, 新規プロジェクトの計画にも利用することとする. 本例題においては, $\alpha=0.35, \beta=0.01$ とする.

OFRAC の実際のプロジェクトではタスクオプションを考慮しておらず，リスク選好は高くない．そのため, 表 3 の灰色で示したタスクについては, プロジェクト当初から難度の低いタスク代替案が実施されていた. 
Table 1 Task Alternatives of Student Formula Design Project .

\begin{tabular}{|c|c|c|c|c|c|}
\hline No. & Task & Task alternative & $m$ & $v$ & $f_{T}$ \\
\hline \multirow[t]{2}{*}{1} & \multirow[t]{2}{*}{ fuel tank } & (1) tubular type & $(0.019,0.041,0.075)$ & 0.70 & 0.60 \\
\hline & & (2) box type & $(0.039,0.081,0.15)$ & 0.30 & 0.60 \\
\hline 2 & radiator & (1) following the previous project & $(0.036,0.050,0.13)$ & 0.50 & 0.60 \\
\hline \multirow[t]{2}{*}{3} & \multirow[t]{2}{*}{ inlet manifold } & (1) JIS funnel & $(0.011,0.025,0.029)$ & 0.70 & 0.70 \\
\hline & & (2) bell-mouth funnel & $(0.016,0.037,0.043)$ & 0.50 & 0.70 \\
\hline \multirow[t]{2}{*}{4} & \multirow[t]{2}{*}{ exhaust manifold } & (1) Inconel & $(0.0021,0.0059,0.011)$ & 0.70 & 0.50 \\
\hline & & (2) carbon steel & $(0.0041,0.012,0.022)$ & 0.50 & 0.50 \\
\hline \multirow[t]{2}{*}{5} & \multirow[t]{2}{*}{ surge tank } & (1) easily disassembled & $(0.0035,0.0059,0.0083)$ & 0.70 & 0.40 \\
\hline & & (2) integrated & $(0.0050,0.0084,0.012)$ & 0.50 & 0.40 \\
\hline \multirow[t]{2}{*}{6} & \multirow[t]{2}{*}{ assist parts of powertrain } & (1) boring powertrain chassis for flow channel & $(0.0012,0.0044,0.010)$ & 0.90 & 0.70 \\
\hline & & (2) boring oil pan for flow channel & $(0.0025,0.0088,0.021)$ & 0.70 & 0.70 \\
\hline \multirow[t]{2}{*}{7} & \multirow[t]{2}{*}{ muffler } & (1) tubular type & $(0.014,0.031,0.046)$ & 0.90 & 0.70 \\
\hline & & (2) box type & $(0.021,0.046,0.070)$ & 0.50 & 0.60 \\
\hline \multirow[t]{2}{*}{8} & \multirow[t]{2}{*}{ differential gear } & (1) multiplate type & $(0.022,0.028,0.034)$ & 0.70 & 0.40 \\
\hline & & (2) helical gear type & $(0.033,0.042,0.051)$ & 0.50 & 0.40 \\
\hline \multirow[t]{2}{*}{9} & propeller shaft & (1) RCV shaft & $(0.066,0.070,0.13)$ & 0.90 & 0.70 \\
\hline & & (2) NTN shaft & $(0.092,0.099,0.18)$ & 0.70 & 0.70 \\
\hline 10 & CVT setting & (1) evaluating both of fuel cost and speed & $(0.0045,0.015,0.028)$ & 0.90 & 0.70 \\
\hline & & (2) prioritizing speed & $(0.0090,0.029,0.056)$ & 0.50 & 0.70 \\
\hline 11 & shift lever & (1) electric paddle shift & $(0.024,0.082,0.12)$ & 0.80 & 0.70 \\
\hline & & (2) air shift & $(0.030,0.10,0.15)$ & 0.70 & 0.70 \\
\hline & & (3) paddle shift & $(0.061,0.20,0.29)$ & 0.50 & 0.80 \\
\hline 12 & alignment geometry & (1) revising rolling center position & $(0.0095,0.014,0.020)$ & 0.90 & 0.80 \\
\hline & & (2) revising suspension layout & $(0.014,0.021,0.030)$ & 0.70 & 0.80 \\
\hline & & (3) revising king pin & $(0.019,0.028,0.040)$ & 0.50 & 0.80 \\
\hline 13 & suspension & (1) machined arm & $(0.014,0.12,0.27)$ & 0.90 & 0.80 \\
\hline & & (2) welded arm & $(0.022,0.18,0.41)$ & 0.70 & 0.80 \\
\hline 14 & arm & (1) CFRP and aluminum & $(0.012,0.023,0.029)$ & 0.90 & 0.50 \\
\hline & & (2) iron & $(0.035,0.068,0.087)$ & 0.40 & 0.60 \\
\hline 15 & front upright & (1) machined aluminum & $(0.0048,0.0066,0.011)$ & 0.70 & 0.70 \\
\hline & & (2) welded iron & $(0.0081,0.011,0.019)$ & 0.30 & 0.70 \\
\hline 16 & rear upright & (1) aluminum machined by 5 axes NC & $(0.0064,0.010,0.013)$ & 0.90 & 0.70 \\
\hline & & (2) aluminum machined by 3 axes NC & $(0.013,0.020,0.025)$ & 0.50 & 0.70 \\
\hline 17 & hub & (1) prioritizing weight saving & $(0.0093,0.061,0.18)$ & 0.90 & 0.80 \\
\hline & & (2) prioritizing manufacturability & $(0.012,0.076,0.23)$ & 0.70 & 0.80 \\
\hline 18 & steering tie rod & (1) revising crevice & $(0.0048,0.035,0.063)$ & 0.70 & 0.40 \\
\hline & & (2) revising mount & $(0.0096,0.069,0.13)$ & 0.50 & 0.70 \\
\hline 19 & packaging & (1) revising weight balance & $(0.037,0.10,0.20)$ & 0.70 & 0.70 \\
\hline 20 & braking system & (1) two facing pods & $(0.0025,0.013,0.023)$ & 0.90 & 0.70 \\
\hline & & (2) one facing pod & $(0.0031,0.016,0.029)$ & 0.70 & 0.70 \\
\hline 21 & footboard box & (1) movable & $(0.0066,0.021,0.026)$ & 0.70 & 0.70 \\
\hline & & (2) fixed & $(0.017,0.053,0.065)$ & 0.50 & 0.70 \\
\hline 22 & front car frame & (1) monocoque & $(0.0028,0.0037,0.0046)$ & 0.90 & 0.60 \\
\hline & & (2) pointed monocoque & $(0.0071,0.0092,0.012)$ & 0.70 & 0.70 \\
\hline & & (3) space frame & $(0.014,0.018,0.023)$ & 0.50 & 0.70 \\
\hline 23 & rear car frame & (1) revising suspension layout & $(0.014,0.017,0.031)$ & 0.70 & 0.70 \\
\hline & & (2) German type & $(0.021,0.026,0.046)$ & 0.50 & 0.40 \\
\hline & & (3) modified German type & $(0.028,0.034,0.061)$ & 0.30 & 0.40 \\
\hline 24 & impact attenuator & (1) carbon fiber & $(0.0068,0.049,0.089)$ & 0.90 & 0.60 \\
\hline & & (2) aluminum honeycomb & $(0.0075,0.054,0.098)$ & 0.70 & 0.60 \\
\hline 25 & cockpit & (1) separated & $(0.013,0.023,0.060)$ & 0.70 & 0.70 \\
\hline & & (2) integrated & $(0.027,0.046,0.12)$ & 0.50 & 0.70 \\
\hline 26 & wing & (1) CFRP female die & $(0.0057,0.0083,0.0096)$ & 0.70 & 0.60 \\
\hline & & (2) GFRP female die & $(0.012,0.017,0.019)$ & 0.50 & 0.60 \\
\hline & & (3) GFRP male die & $(0.023,0.033,0.038)$ & 0.30 & 0.60 \\
\hline 27 & diffuser & (1) large type & $(0.0047,0.0061,0.011)$ & 0.90 & 0.60 \\
\hline & & (2) small type & $(0.0059,0.0077,0.013)$ & 0.50 & 0.60 \\
\hline 28 & cowl & (1) CFRP female die & $(0.0044,0.015,0.019)$ & 0.90 & 0.50 \\
\hline & & (2) GFRP female die & $(0.0055,0.019,0.024)$ & 0.70 & 0.50 \\
\hline 29 & electric equipment & (1) brushless motor & $(0.0025,0.0052,0.0097)$ & 0.70 & 0.60 \\
\hline & & (2) brushed motor & $(0.0031,0.0065,0.012)$ & 0.30 & 0.60 \\
\hline
\end{tabular}




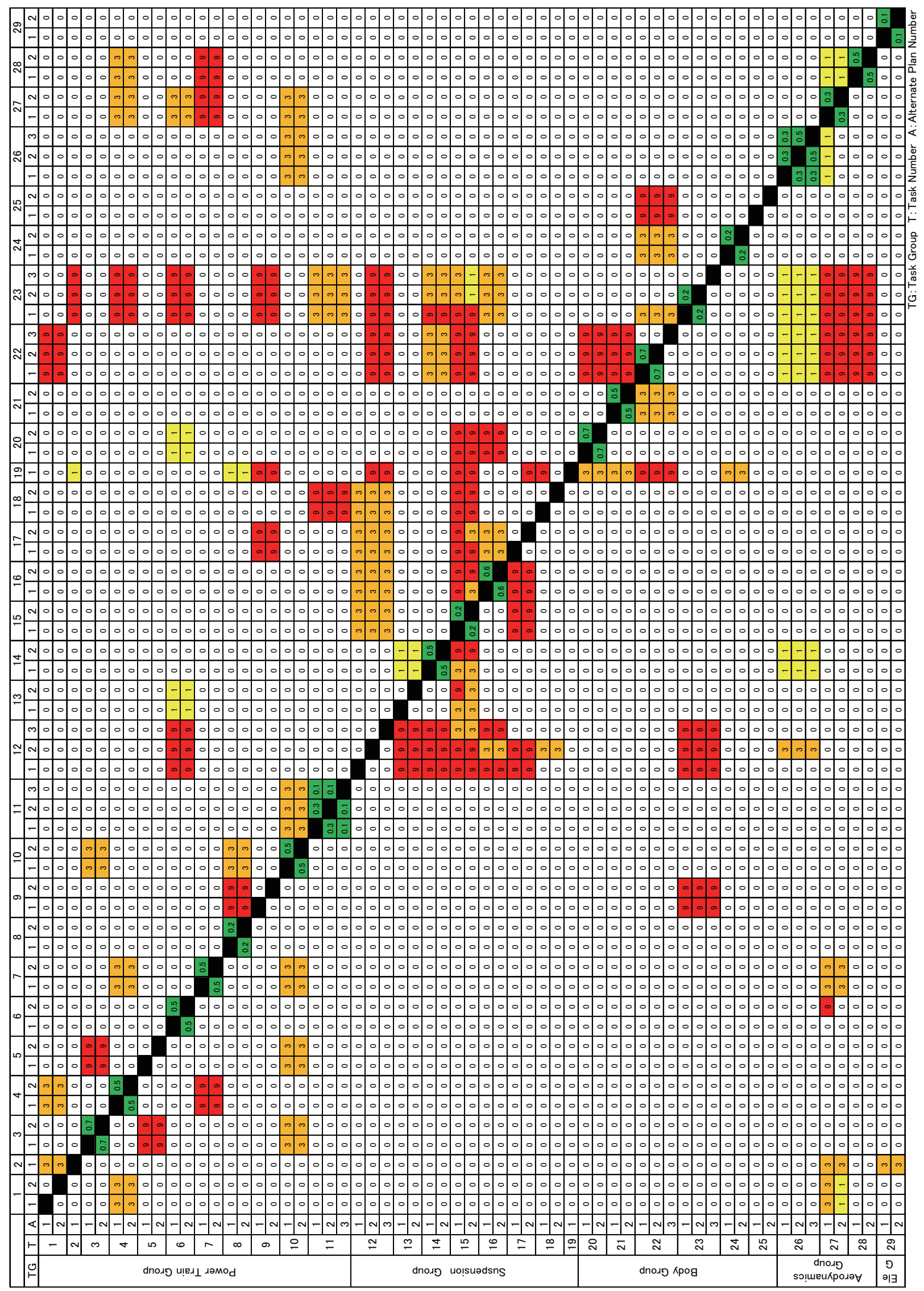


Table 2 Initial Knowledge Level of Designer .

\begin{tabular}{|c|c|c|c|c|c|c|c|c|c|c|c|c|c|c|c|c|}
\hline Task & Task alternative & $\mathrm{A}$ & $\mathrm{B}$ & $\mathrm{C}$ & $\mathrm{D}$ & $\mathrm{E}$ & $\mathrm{F}$ & G & $\mathrm{H}$ & I & $J$ & $\mathrm{~K}$ & $\mathrm{~L}$ & M & $\mathrm{N}$ & $\mathrm{O}$ \\
\hline \multirow[t]{2}{*}{ fuel tank } & (1) tubular type & 0.30 & 0.6 & 0.00 & 0.30 & 0.40 & 0.00 & 0.00 & 0.50 & 0.00 & 0.00 & 0.00 & 0.00 & 0.00 & 0.00 & 0.00 \\
\hline & ) box type & 0.50 & 0.60 & 0.00 & 0.30 & 0.20 & 0.00 & 0.00 & 0.50 & 0.00 & 0.00 & 0.00 & 0.00 & 0.00 & 0.00 & 0.00 \\
\hline 2 radiator & 1) following the prev. & 50 & 0.60 & 0.00 & 0.00 & 0.50 & 0.20 & 0.00 & 0.50 & 0.00 & 0.00 & 0.20 & 0.00 & 0.00 & 0.00 & 0.00 \\
\hline 3 ilt mani. & ) JIS funnel & & 0.60 & 0.60 & 0.00 & 0.00 & 0.00 & 0.00 & 0.60 & 0.60 & & 0.0 & 0.0 & 0.0 & 0.00 & 0.00 \\
\hline & bell-mouth funnel & 50 & 0.60 & 0.60 & 0.00 & 0.00 & 0.00 & 0.00 & 0.60 & 0.60 & 0.00 & 0.00 & 0.00 & 0.00 & 0.00 & 0.00 \\
\hline ex. mani. & (1) Inconel & 20 & 0.30 & 0.00 & 0.00 & 0.30 & 0.00 & 0.00 & 0.30 & 0.00 & 0.2 & 0.00 & 0.00 & 0.00 & 0.30 & 0.00 \\
\hline & (2) carbon steel & 30 & 0.60 & 0.00 & 0.00 & 0.60 & 0.00 & 0.00 & 0.60 & 0.00 & 0.20 & 0.00 & 0.00 & 0.00 & 0.3 & 0.00 \\
\hline 5 surge tank & (1) easily disassembled & 0.30 & 0.60 & 0.60 & 0.00 & 0.00 & 0.00 & 0.00 & 0.60 & 0.20 & 0.00 & 0.00 & 0.00 & 0.00 & 0.00 & 0.00 \\
\hline & (2) integrated & 20 & & 0.60 & 0.00 & 0.00 & 0.00 & 0.00 & 0.60 & 0.20 & 0.00 & 0.00 & 0.00 & 0.0 & 0.0 & 0.00 \\
\hline 6 assist parts & (1) boring p.t. chassis & 0.50 & 0.60 & 0.30 & 0.00 & 0.00 & 0.00 & 0.00 & 0.10 & 0.00 & 0.00 & 0.00 & 0.00 & 0.00 & 0.0 & 0.00 \\
\hline & (2) boring oil pan & 20 & 0.60 & 0.70 & 0.00 & 0.00 & 0.00 & 0.00 & 0.10 & 0.00 & 0.0 & 0.00 & 0.00 & 0.00 & 0.0 & 0.00 \\
\hline 7 muffler & (1) tubular type & 0.50 & 0.60 & 0.60 & 0.00 & 0.00 & 0.00 & 0.00 & 0.60 & 0.00 & 0.40 & 0.00 & 0.00 & 0.00 & 0.60 & 0.00 \\
\hline & (2) box type & .50 & 0.60 & 0.60 & 0.00 & 0.00 & 0.00 & 0.00 & 0.30 & 0.00 & 0.5 & 0.00 & 0.00 & 0.0 & 0.6 & 0.00 \\
\hline 8 diff. gear & (1) multiplate type & 0.60 & 0.00 & 0.00 & 0.00 & 0.00 & 0.00 & 0.00 & 0.00 & 0.00 & 0.00 & 0.00 & 0.00 & 0.00 & 0.00 & 0.00 \\
\hline & (2) helical gear type & .60 & 0.30 & 0.00 & 0.00 & 0.00 & 0.00 & 0.00 & 0.00 & 0.00 & 0.00 & 0.00 & 0.00 & 0.0 & 0.0 & 0.00 \\
\hline $\begin{array}{ll}9 & \text { prp. shaft }\end{array}$ & (1) RCV shaft & 0.20 & 0.30 & 0.00 & 0.00 & 0.00 & 0.00 & 0.00 & 0.30 & 0.00 & 0.00 & 0.00 & 0.00 & 0.00 & 0.00 & 0.00 \\
\hline & (2) NTN shaft & 20 & 0.60 & 0.00 & 0.00 & 0.00 & 0.00 & 0.00 & 0.50 & 0.00 & 0.00 & 0.00 & 0.00 & 0.0 & 0.0 & 0.00 \\
\hline 10 CVT set. & (1) fuel cost and speed & .30 & 0.60 & 0.40 & 0.00 & 0.00 & 0.00 & 0.00 & 0.10 & 0.00 & 0.00 & 0.00 & 0.00 & 0.00 & 0.00 & 0.00 \\
\hline & (2) prioritizing speed & 30 & 0.60 & 0.70 & 0.00 & 0.00 & 0.00 & 0.00 & 0.10 & 0.00 & 0.00 & 0.00 & 0.00 & 0 . & 0.0 & 0.00 \\
\hline 11 shift lever & (1) electric paddle shift & 0.30 & 0.10 & 0.30 & 0.00 & 0.00 & 0.00 & 0.00 & 0.30 & 0.00 & 0.00 & 0.00 & 0.00 & 0.00 & 0.30 & 0.00 \\
\hline & (2) air shift & 50 & 0.60 & 0.60 & 0.00 & 0.50 & 0.00 & 0.00 & 0.60 & 0.00 & 0.00 & 0.00 & 0.00 & 0 & 0.0 & 0.00 \\
\hline & (3) paddle shift & .50 & 0.60 & 0.60 & 0.00 & 0.70 & 0.00 & 0.00 & 0.30 & 0.00 & 0.00 & 0.00 & 0.00 & 0.0 & 0.6 & 0.00 \\
\hline 12 algn. g & (1) revising rolling center & 0.50 & 0.50 & 0.60 & 0.60 & 0.00 & 0.00 & 0.00 & 0.30 & 0.00 & 0.00 & 0.00 & 0.00 & 0.10 & 0.00 & 0.00 \\
\hline & sus. la & & 0.50 & & 0.60 & & 0.00 & 0.00 & 0.50 & 0.00 & & 0.00 & 0.00 & 0 . & & 0.00 \\
\hline & sing king pin & 0.50 & 0.50 & 0.60 & 0.60 & 0.00 & 0.00 & 0.00 & 0.30 & 0.00 & 0.00 & 0.00 & 0.00 & 0.1 & 0.0 & 0.00 \\
\hline 13 sus. & (1) machined arm & 0.20 & 0.30 & 0.00 & 0.70 & 0.00 & 0.00 & 0.00 & 0.30 & 0.00 & 0.00 & 0.00 & 0.00 & 0.10 & 0.00 & 0.00 \\
\hline & ded arm & .20 & & 0.00 & 0.70 & & $0 .($ & 0.00 & 0.60 & 0.00 & 0.0 & 0.0 & 0.00 & 0.1 & 0.0 & 0.00 \\
\hline 14 arm & (1) CFRP and aluminum & 0.40 & 0.50 & 0.00 & 0.00 & 0.00 & 0.60 & 0.00 & 0.60 & 0.00 & 0.00 & 0.00 & 0.00 & 0.2 & 0.00 & 0.00 \\
\hline & ) aron & 50 & & 0. & 0.00 & & 0. & 0.00 & 0 . & 0.1 & & 0.0 & 0.0 & & 0.0 & 0.00 \\
\hline 15 front upright & (1) 1 & 0.20 & 0.60 & 0.00 & 0.60 & 0.00 & 0.00 & 0.00 & 0.40 & 0.00 & 0.00 & 0.00 & 0.00 & 0.20 & 0.00 & 0.00 \\
\hline & $\mathrm{v}$ & 1 & 0 & 0.00 & 0.60 & 0.0 & 0.00 & 0.00 & 0.40 & 0.00 & 0 & 0.00 & 0.00 & 0.20 & 0.00 & 0.00 \\
\hline 16 rear upright & (1) & & 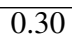 & 0.00 & 0.60 & 0.00 & 0.00 & 0.00 & 0.10 & 0.00 & 0 & 0.00 & 0.00 & 0 . & 0.00 & 0.00 \\
\hline & (2 & & & 0. & 0.60 & 0 . & 0. & 0.00 & 0.50 & 0. & 0 & 0. & 0.00 & 0 & 0 & 0.00 \\
\hline 17 hub & $(1$ & & 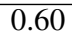 & 0.00 & 0.80 & 0 . & 0 . & 0.00 & 0.10 & 0 . & 0 & 0.0 & 0.00 & 0 & 0 . & 0.00 \\
\hline & 1 & & & 0. & 0 . & 0 & & 0.00 & 0. & & & 0. & & & & 0.00 \\
\hline 18 str. t.r. & $(1)$ & & 0. & 0. & 0.30 & 0 & 0. & 0.20 & 0 . & 0 . & & 0. & 0 . & 0 & 0 & 0.00 \\
\hline & ( & & & 0. & 0.3 & & & 0.20 & 0 . & & & 0. & 0. & & & 0.00 \\
\hline 19 packaging & $\mathrm{W}$ & 0.4 & 0 . & 0.00 & 0.30 & 0.00 & 0.00 & 0.00 & 0.30 & 0.00 & $0 .($ & 0.00 & 0.00 & 0. & 0.00 & 0.00 \\
\hline 20 braking & ing pods & & & 0.00 & 0.30 & 0. & 0. & 0.0 & 0.60 & 0. & & 0.0 & 0 . & 0 & 0 & 0.00 \\
\hline & (2) $\mathrm{c}$ & & & 0. & & 0 . & & 0.00 & 0.30 & & & 0.0 & 0.6 & 0. & & 0.00 \\
\hline 21 footboard box & (1) movable & 0.20 & 0 . & 0.00 & 0.30 & 0 . & 0 . & 0.20 & 0.10 & 0. & 0 & 0.0 & 0.30 & 0. & 0.0 & 0.00 \\
\hline & (2) $\mathrm{fi}$ & & & & & 0 & & & 0. & & & & 0.6 & & 0.1 & 0.00 \\
\hline 22 front c.f. & (1) monocoque & 0.50 & 0.30 & 0.00 & 0.30 & 0.30 & 0.30 & 0.40 & 0.30 & 0.00 & 0.00 & 0.00 & 0.40 & 0.00 & 0.00 & 0.00 \\
\hline & monoc & & & & & 0 & & 0.4 & 0. & & & 0 & 0. & & & 0.00 \\
\hline & (3) space frame & & 0 & & 0.30 & 0 & & 0.40 & 0 . & & & 0. & 0.6 & 0. & 0. & 0.00 \\
\hline 23 rear c.f. & (1) revising sus. layout & 0.20 & 0.60 & 0.60 & 0.30 & 0.60 & 0.60 & 0.00 & 0.60 & 0.00 & 0.0 & 0.00 & 0.00 & 0.00 & 0.00 & 0.00 \\
\hline & i type & & 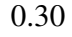 & & & 0 & & $0 .($ & 0 . & & & & 0. & & & 0.00 \\
\hline & (3) modified Germ & & 0 . & & 0.30 & 0. & & 0.00 & 0.30 & 0.00 & 0. & 0.0 & 0.00 & 0.00 & 0.00 & 0.00 \\
\hline 24 imp. att. & (1) carbon fiber & 0.20 & 0 . & 0.00 & 0.30 & 0.00 & 0.00 & 0.20 & 0.60 & 0.00 & 0.00 & 0.00 & 0.00 & 0.00 & 0.00 & 0.00 \\
\hline & (2) aluminum ho & & & & 0.30 & 0 . & & 0.20 & 0.60 & 0.00 & & 0.00 & 0.00 & 0.00 & 0.00 & 0.00 \\
\hline 25 cockpit & (1) separated & 0.50 & 0.60 & 0.00 & 0.30 & 0.00 & 0.00 & 0.40 & 0.60 & 0.00 & 0.00 & 0.00 & 0.00 & 0.00 & 0.00 & 0.00 \\
\hline & ed & & & 0.00 & 0.30 & 0.00 & 0.00 & 0.30 & 0.30 & 0.00 & 0.00 & 0.00 & 0.00 & 0.0 & 0.00 & 0.00 \\
\hline 26 wing & CFRP female die & 0 & 0.30 & 0.30 & 0.00 & 0.00 & 0.00 & 0.20 & 0.60 & 0.00 & 0.00 & 0.00 & 0.00 & 0.00 & 0.00 & 0.20 \\
\hline & P fen & & & 0. & 0.00 & 0. & 0. & 0.20 & 0 . & $0 .($ & 0. & 0.0 & 0.00 & 0. & 0.00 & 0.20 \\
\hline & GFRP male & & & 0. & 0.00 & 0.00 & 0.00 & 0.20 & 0.60 & 0.00 & 0.00 & 0.00 & 0.00 & 0.00 & 0.00 & 0.20 \\
\hline 27 diffuser & (1) large type & 0.20 & 0.30 & 0.30 & 0.00 & 0.00 & 0.20 & 0.00 & 0.30 & 0.00 & 0.00 & 0.00 & 0.00 & 0.00 & 0.00 & 0.20 \\
\hline & & 0.2 & 0 . & 0.00 & 0.00 & 0.00 & 0.20 & 0.00 & 0.30 & 0.00 & 0.00 & 0.00 & 0.00 & 0.00 & 0.00 & 0.50 \\
\hline 28 cowl & CFRP female die & & 0.30 & 0.00 & 0.00 & 0.00 & 0.20 & 0.00 & 0.60 & 0.00 & 0.00 & 0.00 & 0.00 & 0.00 & 0.00 & 0.00 \\
\hline & Iema & 0.20 & 0.60 & 0.00 & 0.00 & 0.00 & 0.20 & 0.00 & 0.30 & 0.00 & 0.00 & 0.00 & 0.00 & 0.00 & 0.00 & 0.00 \\
\hline 29 electric eq & or & & 0.30 & 0.00 & 0.00 & 0.00 & 0.00 & 0.00 & 0.30 & 0.00 & 0.00 & 0.20 & 0.00 & 0.00 & 0.50 & 0.00 \\
\hline & (2) bbl & & 0.30 & 0.00 & 0.00 & 0.00 & 0.00 & 0.00 & 0.30 & 0.00 & 0.00 & 0.50 & 0.00 & 0.00 & 0.5 & 0.00 \\
\hline
\end{tabular}


Table 3 Scheduling of OFRAC .

\begin{tabular}{|c|c|c|c|c|c|c|c|c|c|c|c|c|c|c|c|c|c|}
\hline Designer & \multicolumn{5}{|c|}{ A } & \multicolumn{2}{|c|}{ B } & \multicolumn{2}{|c|}{$\mathrm{C}$} & \multicolumn{3}{|c|}{$\mathrm{D}$} & \multicolumn{2}{|c|}{$\mathrm{E}$} & \multicolumn{3}{|c|}{$\mathrm{F}$} \\
\hline Task No. & 9 & 16 & 18 & 19 & 23 & 8 & 24 & 6 & 10 & 12 & 13 & 17 & 1 & 11 & 2 & 26 & 28 \\
\hline Time & 13. & 100 & 5.0 & 8.0 & 69. & 22. & 5.0 & 150 & 90. & 120 & 4.0 & 11. & 12. & 6.0 & 17. & 87. & 30. \\
\hline$p$ & 0.29 & 0.32 & 0.60 & 0.65 & 0.78 & 0.34 & 0.60 & 0.42 & 0.34 & 0.52 & 0.57 & 0.44 & 0.62 & 0.48 & 0.88 & 0.75 & 0.34 \\
\hline Designer & \multicolumn{2}{|c|}{ G } & $\mathrm{H}$ & I & \multicolumn{2}{|c|}{$\mathrm{J}$} & $\mathrm{K}$ & \multicolumn{2}{|c|}{ L } & M & $\mathrm{N}$ & $\mathrm{O}$ & \multicolumn{5}{|c|}{ Meeting } \\
\hline Task No. & 22 & 25 & 15 & 5 & 4 & 7 & 29 & 20 & 21 & 14 & 3 & 27 & DR & DT1 & DT2 & DT3 & DT4 \\
\hline Time & 72. & 36. & 130 & 59. & 42. & 43. & 94. & 22. & 48. & 25. & 58. & 80. & 24. & 18. & 18. & 18. & 17. \\
\hline$p$ & 0.24 & 0.85 & 0.05 & 0.60 & 0.36 & 0.21 & 0.73 & 0.55 & 0.32 & 0.34 & 0.17 & 0.66 & & & & & \\
\hline
\end{tabular}

\section{$7 \cdot 2$ 最適化結果}

収集したプロジェクト情報のもとで, 計画案の最適化を行った. 実際の計算にあたっては, 多目的最適化に適 した遺伝的アルゴリズムである NCGA (Watanabe et al., 2003)を用いた. 許容達成確率は $p_{c}=0.4$ とした.

フェーズ 1 の最適化計算の過程を図 6 に示す。図 6 より，世代を重ねるにつれてパレート面を形成しながら収束 していることが確認できた。本計算例では 500 世代でほぼ収束しており，パレート解が得られたと判断した。ま た，到達度 (TPL)の目標達成確率，整合度 (IL) の目標達成確率，および性能ポテンシャルの間にトレードオフの 関係が存在することが確認できた. 第 500 世代のパレート解のうち，いくつかの特徵的な解を選択し，フェーズ 2 を行った. 本計算例では, 性能ポテンシャルが高い解 (plan 1), 2 つの視点の目標達成確率が高い解 (plan 2), 3 つ の目的関数值のバランスがよい解 (plan 3)の 3 つを選んだ. その最適化結果を図 7 に示す. 全体として，3つの目 的関数のもとでのパレート解が得られていることが確認できた.

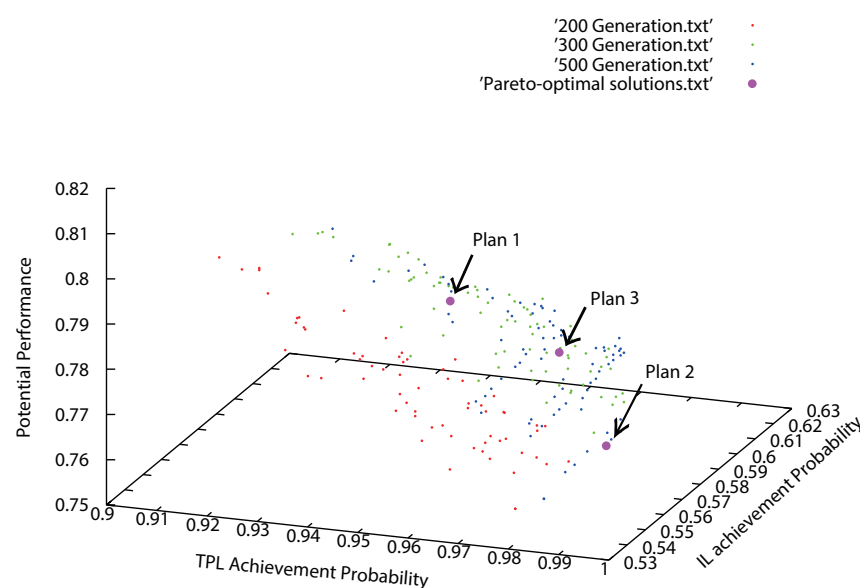

Fig. 6 Pareto-optimal solutions of phase 1. Pareto surface is formed and converges at 500th generation. It is confirmed that there are trade-off among three objective functions.

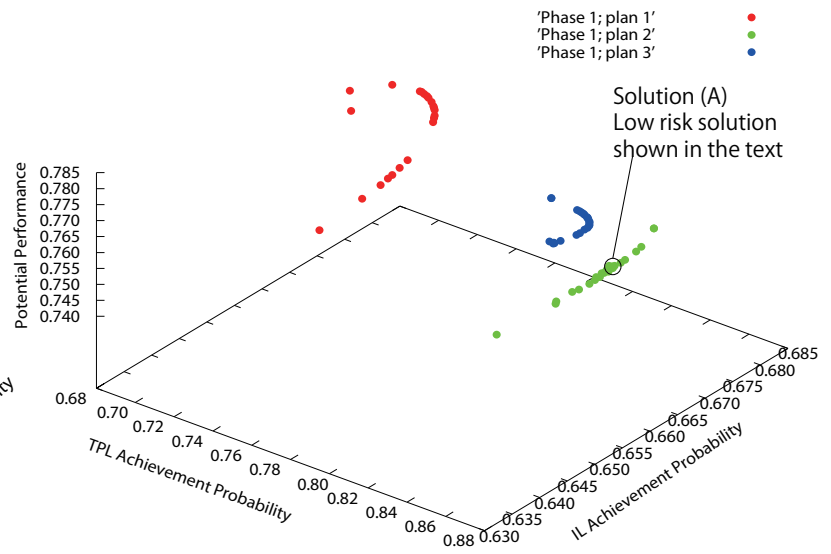

Fig. 7 Pareto-optimal solutions of phase $2 . \quad$ Paretooptimal solutions are obtained for the three objective functions.

OFRAC が実際に実施したプロジェクト計画の内容の評価指標の值は, $P=0.43, Q=0.66, V=0.67$ であった. 図 7 のパレート解はいずれもこの值を上回っている.つまり, 低リスクで高い性能ポテンシャルが期待できる優 れたプロジェクト計画案を，提案手法により導出できることが確認できた.

\section{8. 考察}

前節で得られた最適解と, 実際に実施されたプロジェクトの結果の比較を通じて, 3.4 節で述べた各課題が提案 手法によって解決されたかどうかを考察する.

\section{$8 \cdot 1$ タスクオプションによるリスク評価とリスク低減効果について}

まず， 3.4 節の課題 1, すなわち, 本研究で提案したタスクオプションの概念とそれに基づくリスク評価法の効 果について検証する. 表 3 の $p$ の行に実際の OFRAC プロジェクト計画における各タスクの到達目標達成確率, 表 4 の $\tilde{p}$ の行に, 目標達成確率が高いスケジューリング案の解 (図 7 中の解 $(\mathrm{A})$ ) における各タスクの到達目標達成確 
Table 4 Solutions of time allocation; low risk. Higher difficult tasks are allocated more design time e.g., power train assist parts design task (6), alignment geometry task (12). A backup option is chosen for exhaust manifold design task (4), power train assist parts (6), front frame design task (22) and so on. As the results, project failure risk is mitigated, while potential performance is sacrificed a little.

\begin{tabular}{|c|c|c|c|c|c|c|c|c|c|c|c|c|c|c|c|c|c|}
\hline Designer & \multicolumn{5}{|c|}{ A } & \multicolumn{4}{|c|}{ B } & \multicolumn{2}{|c|}{$\mathrm{C}$} & \multicolumn{3}{|c|}{ D } & $\mathrm{E}$ & $\mathrm{F}$ & $\mathrm{G}$ \\
\hline Task & 8 & 9 & 12 & 14 & 25 & 5 & 7 & 10 & 18 & 6 & 23 & 15 & 16 & 17 & 11 & 27 & 22 \\
\hline Time & 0.90 & 23. & 160 & 23. & 50. & 1.3 & 24.3 & 29.7 & 1.3 & 210 & 29. & 61. & 44. & 7.5 & 28. & 160 & 140 \\
\hline$\tilde{p}$ & 1.0 & 0.96 & 1.0 & 1.0 & 1.0 & 1.0 & 0.93 & 0.74 & 1.0 & 0.93 & 1.0 & 0.14 & 0.84 & 1.0 & 0.69 & 0.66 & 0.89 \\
\hline Designer & \multicolumn{4}{|c|}{$\mathrm{H}$} & I & $\mathrm{J}$ & $\mathrm{K}$ & $\mathrm{L}$ & $\mathrm{M}$ & $\mathrm{N}$ & \multicolumn{2}{|c|}{$\mathrm{O}$} & \multicolumn{5}{|c|}{ Meeting } \\
\hline Task & 20 & 24 & 26 & 28 & 3 & 4 & 13 & 21 & 1 & 29 & 2 & 19 & DR & DT1 & DT2 & DT3 & DT4 \\
\hline Time & 50. & 7.7 & 40. & 7.3 & 69. & 94. & 89. & 98. & 38. & 67. & 32. & 41. & 17. & 11. & 11. & 13. & 0.0 \\
\hline$\tilde{p}$ & 0.88 & 1.0 & 1.0 & 1.0 & 1.0 & 0.80 & 0.85 & 0.89 & 0.84 & 0.93 & 1.0 & 1.0 & & & & & \\
\hline
\end{tabular}

率を示す. なお，表 4 の黄色はバックアップオプションが実施されたタスクであることを示す.どのタスクについ ても, 表 4 の方が実際のプロジェクトよりも到達目標確率が高くなっており, プロジェクト失敗リスクが低減さ れていることが確認できる.

実際の OFRAC プロジェクトにおいて難度の低いタスク代替案が採用されていた 12 個のタスク (表 3 の灰色) に ついての比較を図 8 に示す. 図 8 の赤色の棒グラフが実際の OFRAC プロジェクト計画の $p$ の值である. 解 (A) に おけるタスクは, タスクオプションを考慮しなかったもの(橙色の棒グラフ), タスクオプションを考慮したものの すべてのバックアップオプションの選択確率が 0 , つまり優先オプションが必ず選択されたもの $\left(c_{i, 0}=1\right.$, 緑色の 棒グラフ), $c_{i, z}>0$ となるバックアップオプションが存在したもの (青色の棒グラフ, 表 4 の黄色のタスク), の 3 つのカテゴリーに分類されている.

いずれのカテゴリーについても目標達成確率の向上に成功しており, 本研究で提案したリスク評価による最適 計画法が有効に働いていることがわかる. 1 番目，2 番目については難度の高いタスク代替案を採用しながらの向 上である.このうち，1番目のカテゴリーについては，タスクオプションは有効ではなかったものの，組織構造や スケジューリングの調整により $\tilde{p}$ 值を改善したと考えられる. 2 番目のカテゴリーについては, バックアップオプ ションは採用されなかったが, タスクオプションを考慮することにより, 難度の高いタスク代替案の実施のリスク を軽減することができた. 3 番目のカテゴリーは, 最終的には実際の OFRAC と同じ難度の低いタスク代替案を採 用することになったが, そのリスクは軽減された.

以上の考察により, 課題 1 が解決できたと考えられる.

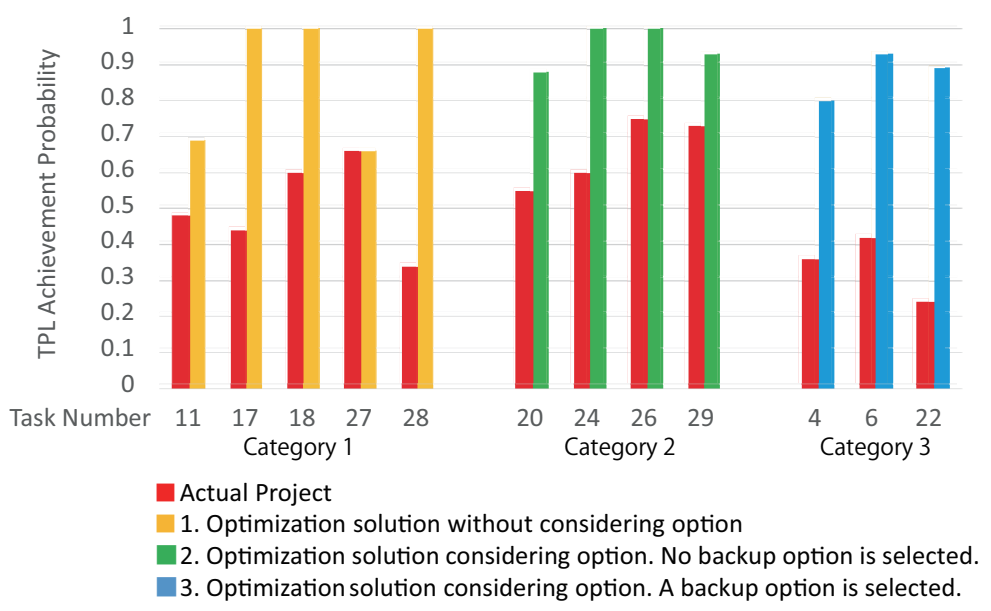

Fig. 8 Comparison of TPL Achievement Probability. Although a task option is not available for the tasks of category 1 and 2, those tasks can expect higher TPL achievement probability than the actual project. A task option works better for the tasks of category 2 and 3 . 


\section{$8 \cdot 2$ 様々な要因の考慮による最適計画の立案について}

次に， 3.4 節の課題 2 , すなわち設計プロセスに関連する様々な要因を同時に考慮することによる最適解の妥当 性について, 得られた最適計画案の内容を詳しく調べることにより考察する. 図 9 は, フェーズ 1 で選択した 3 つのパレート解のうちの, 目標達成確率が高い組織編成案 (plan 2) の内容を示したものである. 実際の組織編成で は, パワートレイン, フレームなど, 車体の主要な部位に対応して 5つのタスクグループが編成されていたが, こ の組織編成案では 4つのタスクグループが存在し, 依存関係の強いタスク同士が同じタスクグループに編成され たり, グループが違っても, 同一設計者が担当する傾向が強いことが分かった. その結果, タスク間の整合度が高 くなっているものと考えられる.

フェーズ 2 につても, 図 7 中の解 (A) の内容を調べた. 表 4 に, その案における, 各タスク, DR, 各タスク グループのミーティングへの配分時間, および各タスクの目標達成確率 $\tilde{p}$ を示す. A O は担当の設計者を示す. 比較的難度の高いタスク (6. パワートレイン補器, 12. アラインメント・ジオメトリ, など) に対して, より多くの 設計時間を与えられ, また, バックアップオプションの選択 (表 4 中で黄色で示した 4. 排気マニフォールド, 6. パ ワートレイン補器, 22. フロントフレーム) が行われていた. その結果, 性能ポテンシャルをやや犠牲にしても, リ スクが低くなっているものと考えられる.

以上の考察により, 課題 2 が解決できたと考えることができる.

\section{$8 \cdot 3$ パレート最適解の導出について}

図 7 より，3つの目的関数のもとでの多様なパレート解が導出できていることは明らかである. つまり 3.4 節の 課題 3 が解決できたと考えることができる.

\section{$8 \cdot 4$ 今後の課題について}

最後に, 残された課題について述べる.

手法の検証について，7章で取り上げた OFRAC プロジェクトは 1 つの例ではあるが，7.1節で述べたように，一 般的な設計開発プロジェクトの性質を持ち, また, 高い水準の工学知識と新規なアイデアが求められるプロジェク トであり，そこで得られた知見は汎用的なものであると考えられる. 一方で, 提案手法をより洗練化するために は，様々なケーススタディを実施する必要がある。例えば，今回取り上げた OFRAC のプロジェクトはリスク選 好が低い場合であったが，リスク選好が高いプロジェクトに対しても同様の効果を得ることができるかどうかは 検証の余地が残されている. 表4の計算結果によると，もともと高難度の代替案が採用されていたタスク (例えば 8. デファレンシャルギア設計など) についても性能ポテンシャルを維持しつつリスクを低減できる傾向を見て取 ることができる. このことから, 提案手法は, リスク選好が高いプロジェクトに対しても同様の効果をもたらす ことができると考えられる. その具体的な検証は今後の課題である.

本研究の計算例では, 想定したタスク代替案の数が限られているため, バックアップオプションを比較的容易に 構成できた. しかしながら, 大規模なプロジェクトにおいては, タスク代替案が多数で, また, 切り替え可能な代 替案が限定されるなどの制約で, その構成が困難となる可能性もある. この課題に対しては, 例えばイベントツ リー分析法を用いて体系的にバックアップオプションを構成する手法を確立することで解決できると考えられる.

\section{9. 結 論}

本研究では, 設計開発プロジェクトにおけるタスクオプションの概念を導入し, タスクオプションを考慮して リスクマネジメントを行うことを想定した設計開発プロジェクトの最適計画を二段階多目的最適化法 (野間口他, 2012)に基づいて実施する手法を提案した. プロジェクト計画案の評価指標として, プロジェクト目標が達成され た場合に期待できる製品性能の高さと, 知識・経験不足による目標達成失敗のリスクの 2 つ視点に着目し, その 下での最適な解を得るためのプロジェクト計画手法を提案した. 提案手法を学生フォーミュラプロジェクトの計画 問題に適用し, 提案した手法の有効性を検証した. 今後の展望としては, リスク要因分析手法 (Smith and Merritt, 2002)などを利用することにより，より包括的なリスク管理手法へ展開することなどが考えられる. 
Nomaguchi, Dong, Horinouchi and Fujita, Transactions of the JSME (in Japanese), Vol.83, No.854 (2017)

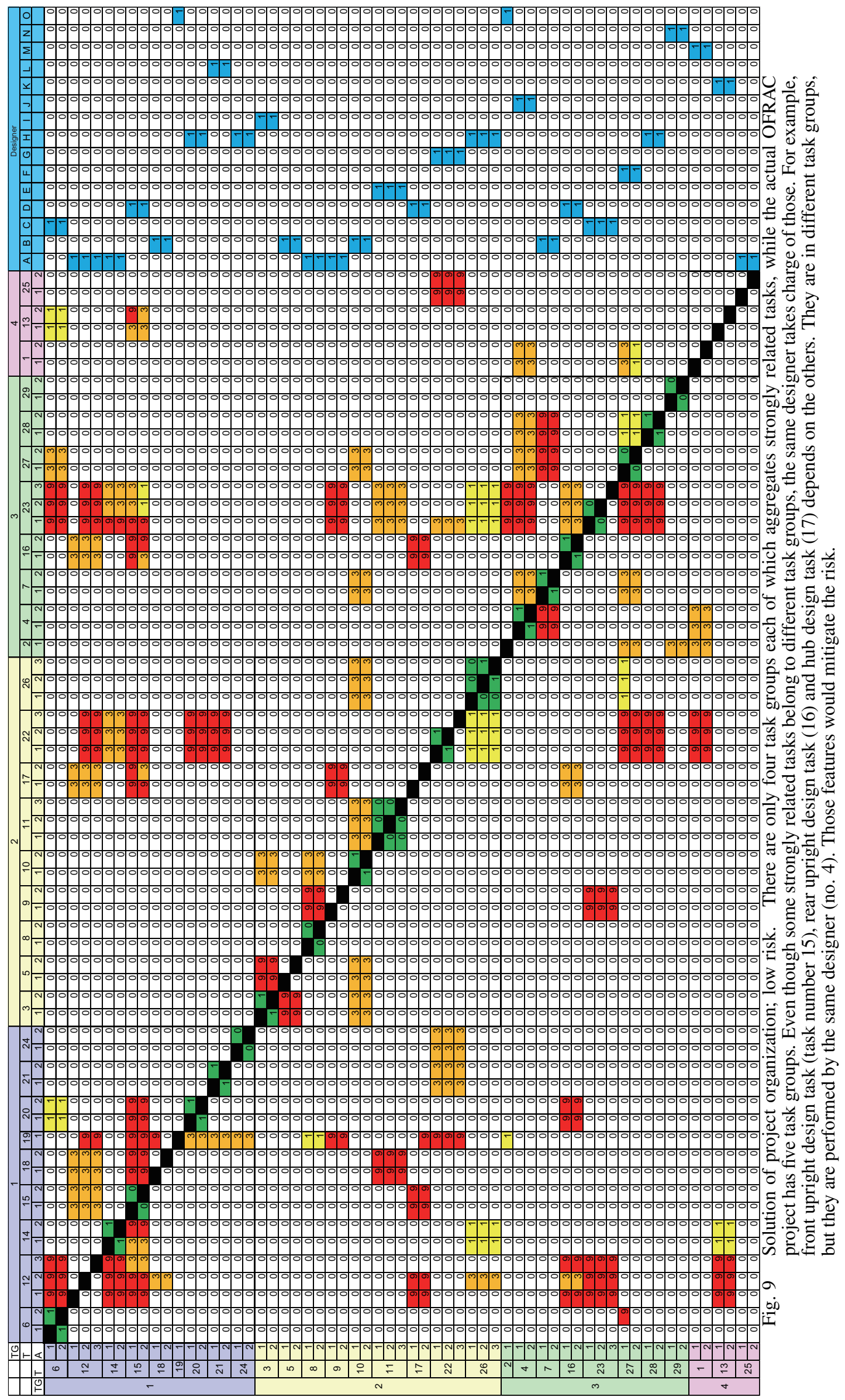


最後に, 本研究における事例分析やデータ収集に協力して頂いた OFRAC の各位に深く謝意を表する. 本研究 は JSPS 科研費 JP24760120 の助成を受けたものである.

\section{文献}

Baldwin, C. Y. and Clark, K. B., Design Rules, Vol. 1: The Power of Modularity (2000), MIT Press, (邦訳: カーリス・ $\mathrm{Y}$ ・ボールドウィン, キム・B・クラーク, (安藤晴彦 訳), デザイン・ルール - モジュール化パワー -, (2004), 東 洋経済新報社).

Black, F. and Scholes, M., The pricing of options and corporate liabilities, The Journal of Political Economy, Vol. 81, No. 3 (1973), pp. 637-654.

Clark, K. B. and Fujimoto, T., The power of product integrity, Harvard Business Review, Vol. 68, No. 6 (1990), pp. $107-118$.

江口隆夫, 森弘惊一, 古賀毅, 戦略オプションを導入したリアルオプションによる製品開発プロジェクトの事業性評 価, 日本機械学会論文集, Vol. 81, No. 825 (2015), DOI:10.1299/transjsme.14-00398.

Engel, A. and Browning, T. R., Designing systems for adaptability by means of architecture options, Systems Engineering, Vol. 11, No. 2 (2008), pp. 125-146.

Eppinger, S. D., Whitney, D. E., Smith, R. and Gebala, D., A model-based method for organizing tasks in product development, Research in Engineering Design, Vol. 6, No. 1 (1994), pp. 1-13.

Fang, C., Marle, F., Zio, E. and Bocquet, J.-C., Network theory-based analysis of risk interactions in large engineering projects, Reliability Engineering and System Safety, Vol. 106 (2012), pp. 1-10.

日本リアルオプション学会, リアルオプションと経営戦略 (2006), シグマベイスキャピタル.

Koh, E., Caldwell, N. and Clarkson, P., A method to assess the effects of engineering change propagation, Research in Engineering Design, Vol. 23, No. 4 (2012), pp. 329-351.

Myers, S. C., Finance theory and financial strategy, Interfaces, Vol. 14, No. 1 (1984), pp. 126-137.

野間口大, 堤大輔, 藤田喜久雄, 到達度に着目した評価モデルに基づく設計プロセス計画支援手法, 日本機械学会論 文集 C 編, Vol. 75, No. 751 (2009), pp. 749-759.

野間口大, 松安亮典, 堀之内貴大, 藤田喜久雄, タスクの到達度とタスク間の整合度の多目的最適化による設計プロ ジェクト計画法に関する研究, 日本機械学会論文集 C 編, Vol. 78, No. 795 (2012), pp. 3812-3828.

Nonaka, I. and von Krogh, G., Tacit knowledge and knowledge conversion: controversy and advancement in organizational knowledge creation theory, Organization Science, Vol. 20, No. 3 (2009), pp. 635-652.

Shapiro, D., Curren, M. and Clarkson, P., DPCM: a method for modelling and analysing design process changes based on the Applied Signposting Model, Journal of Engineering Design, Vol. 27, No. 11 (2016), pp. 785-816.

Sharman, D. and Yassine, A., Architectural valuation using the design structure matrix and real options theory, Concurrent Engineering Research and Applications, Vol. 15, No. 2 (2007), pp. 157-173.

Smith, P. G. and Merritt, G. M., Proactive Risk Management (2002), Productivity Press, (邦訳 : 実践・リスクマネジメ ント, 澤田美樹子 訳, 生産性出版 (2003)).

Sullivan, K. J., Griswold, W. G. and Hallen, Y. C. B., The structure and value of modularity in software design, Proceedings of the 8th European software engineering conference held jointly with 9th ACM SIGSOFT international symposium on Foundations of software engineering (2001), pp. 99-108.

Watanabe, S., Hiroyasu, T. and Miki, M., Multi-objective rectangular packing problem and its applications, Lecture Notes in Computer Science, Vol. 2632, No. 1 (2003), pp. 565-577.

\section{References}

Baldwin, C. Y. and Clark, K. B., Design Rules, Vol. 1: The Power of Modularity (2000), MIT Press.

Black, F. and Scholes, M., The pricing of options and corporate liabilities, The Journal of Political Economy, Vol. 81, No. 3 (1973), pp. 637-654. 
Clark, K. B. and Fujimoto, T., The power of product integrity, Harvard Business Review, Vol. 68, No. 6 (1990), pp. 107-118.

Eguchi, T., Morihiro, J. and Koga, T., Business value estimation of product development project by introducing strategic option into real option, Transactions of the Japan Society of Mechanical Engineers (in Japanese), Vol. 81, No. 825 (2015), DOI:10.1299/transjsme.14-00398.

Engel, A. and Browning, T. R., Designing systems for adaptability by means of architecture options, Systems Engineering, Vol. 11, No. 2 (2008), pp. 125-146.

Eppinger, S. D., Whitney, D. E., Smith, R. and Gebala, D., A model-based method for organizing tasks in product development, Research in Engineering Design, Vol. 6, No. 1 (1994), pp. 1-13.

Fang, C., Marle, F., Zio, E. and Bocquet, J.-C., Network theory-based analysis of risk interactions in large engineering projects, Reliability Engineering and System Safety, Vol. 106 (2012), pp. 1-10.

Japan Association of Real Options and Strategy, Real Options and Management Strategy (2006), Sigma Base Capital (in Japanese).

Koh, E., Caldwell, N. and Clarkson, P., A method to assess the effects of engineering change propagation, Research in Engineering Design, Vol. 23, No. 4 (2012), pp. 329-351.

Myers, S. C., Finance theory and financial strategy, Interfaces, Vol. 14, No. 1 (1984), pp. 126-137.

Nomaguchi, Y., Tsutsumi, D. and Fujita, K., Design process planning method with attainment-based evaluation model, Transactions of the Japan Society of Mechanical Engineers, Series C, Vol. 75, No. 751 (2009), pp. 749-759 (in Japanese).

Nomaguchi, Y., Matsuyasu, R., Horinouchi, T. and Fujita, K., Design process planning by multi-objective optimization of technical performance and product integrity, Transactions of the Japan Society of Mechanical Engineers, Series C, Vol. 78, No. 795 (2012), pp. 3812-3828 (in Japanese).

Nonaka, I. and von Krogh, G., Tacit knowledge and knowledge conversion: controversy and advancement in organizational knowledge creation theory, Organization Science, Vol. 20, No. 3 (2009), pp. 635-652.

Shapiro, D., Curren, M. and Clarkson, P., DPCM: a method for modelling and analysing design process changes based on the Applied Signposting Model, Journal of Engineering Design, Vol. 27, No. 11 (2016), pp. 785-816.

Sharman, D. and Yassine, A., Architectural valuation using the design structure matrix and real options theory, Concurrent Engineering Research and Applications, Vol. 15, No. 2 (2007), pp. 157-173.

Smith, P. G. and Merritt, G. M., Proactive Risk Management (2002), Productivity Press.

Sullivan, K. J., Griswold, W. G. and Hallen, Y. C. B., The structure and value of modularity in software design, Proceedings of the 8th European software engineering conference held jointly with 9th ACM SIGSOFT international symposium on Foundations of software engineering (2001), pp. 99-108.

Watanabe, S., Hiroyasu, T. and Miki, M., Multi-objective rectangular packing problem and its applications, Lecture Notes in Computer Science, Vol. 2632, No. 1 (2003), pp. 565-577. 